\title{
La presse et le sentiment national chez les Roumains
}

Cornelia Bodea

\section{(2) OpenEdition}

Journals

Édition électronique

URL : http://journals.openedition.org/etudesbalkaniques/434

ISSN : 2102-5525

\section{Éditeur}

Association Pierre Belon

\section{Édition imprimée}

Date de publication : 1 janvier 2001

Pagination : 45-61

ISBN : 2-910860-10-8

ISSN : $1260-2116$

\section{Référence électronique}

Cornelia Bodea, "La presse et le sentiment national chez les Roumains », Études balkaniques [En ligne] 8 | 2001, mis en ligne le 08 avril 2009, consulté le 02 mai 2019. URL : http://journals.openedition.org/ etudesbalkaniques/434

Ce document a été généré automatiquement le 2 mai 2019.

Tous droits réservés 


\section{La presse et le sentiment national chez les Roumains}

Cornelia Bodea

AUTEUR

CORNELIA BODEA

Académie des Sciences, Bucarest 